
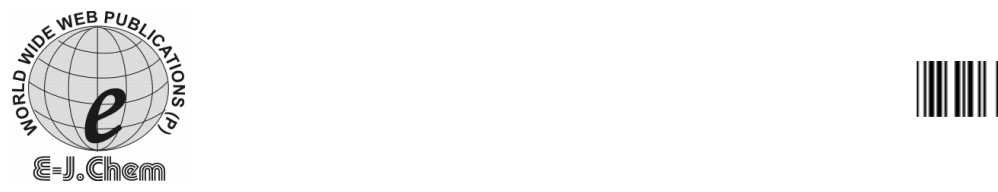

CODEN ECJHAO

E-Journal of Chemistry

http://www.e-journals.net

Vol. 3, No.2, pp 78-82, May 2006

\title{
Spectrophometric Determination of Nelfinavir Mesylate
}

\author{
K.VANITHA PRAKASH and JANGALA VENKATESWARA RAO* \\ Department of Pharmaceutical Chemistry, \\ Sultan-Ul-Uloom College of Pharmacy, \\ Mount Pleasant, Road No. 3, Banjara Hills, Hyderabad-500 034. \\ Email:jvrao1963@yahoo.co.in
}

Received 31 January 2006; Accepted 14 April 2006

\begin{abstract}
Two new simple, sensitive, rapid and economical Spectrophotometric Methods (A and B) have been developed for the determination of Nelfinavir Mesylate in pharmaceutical bulk and tablet dosage form. The method A is based on the reaction of Nelfinavir with ferric chloride, potassium ferricyanide and hydrochloric acid to form a bluish green colored chromogen. The Method B is based on the formation of blood red colored chromogen with Ferric chloride and 1,10-phenanthroline. The absorbances of the chromogen were measured at their respective wavelength of maximum absorbance against the corresponding reagent blank. The proposed methods have been successfully applied to the analysis of the bulk drug and its tablet dosage form. The methods have been statistically evaluated and were found to be precise and accurate.
\end{abstract}

Key words: Nelfinavir Mesylate, Ferric chloride, Potassium ferricyanide, 1,10-phenanthroline. Ultraviolet-Visible double beam spectrophotometer.

\section{Introduction}

Nelfinavir Mesylate ${ }^{1}$ is a novel HIV-1 protease inhibitor, with a chemical name (3S, $4 \mathrm{aS}$, 8aS)-N- (1,1-Dimethylethyl) decahydro-2- [(2R, 3R)-2-hydroxy-3- [(3-hydroxy-2-methyl benzoyl) amino]-4-(phenylthio) butyl]-3-isoquinolinecarboxamide methanesulfonate .It is an antiretroviral drug that acts by binding reversibly to HIV protease thereby preventing cleavage of the viral precursor polyproteins. It is official in Martindale ${ }^{2}$-The Extra 
pharmacopoeia. Literature survey reveals many Chromatographic methods ${ }^{3-10}$ for the determination of Nelfinavir in biological fluids and in combination with other antivirals and very few Spectrophotometric methods ${ }^{11-13}$ only. Therefore the need for fast, low cost and selective method is obvious especially for routine Quality Control analysis of pharmaceutical formulation.

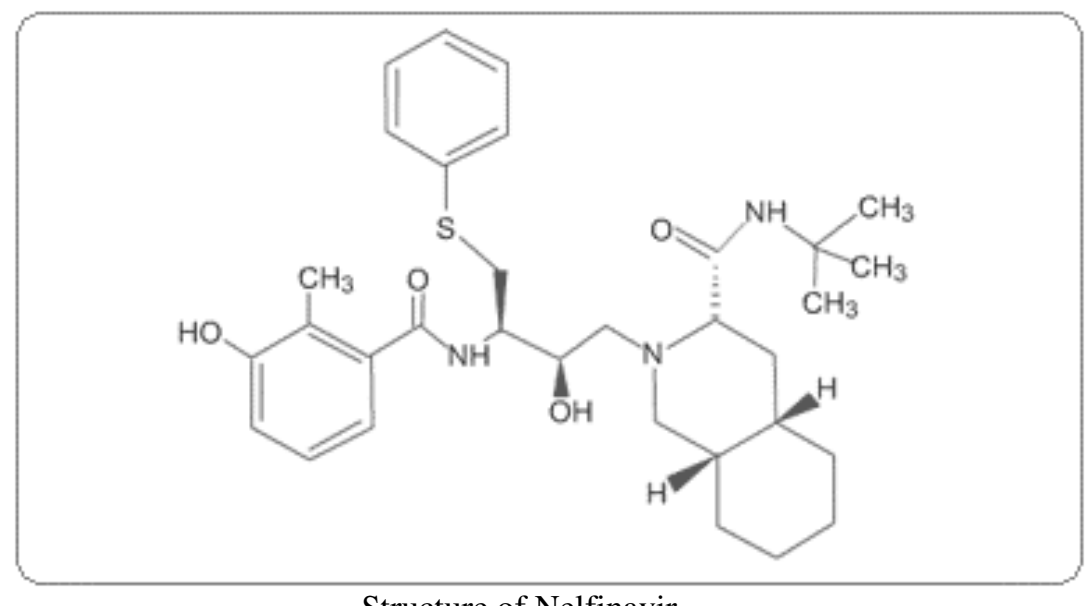

Structure of Nelfinavir

\section{Experimental}

Instrument

Elico double beam Ultraviolet-Visible double beam spectrophotometer SL-164 with $1 \mathrm{~cm}$ matched quartz cells was used for all spectral measurements.

\section{Reagents}

All the chemical used were of analytical reagent grade. All the solutions were freshly prepared with distilled water. For Method A aqueous solutions of Ferric chloride $(0.3 \%$ $\mathrm{w} / \mathrm{v})$, potassium ferricyanide $(0.1 \% \mathrm{w} / / \mathrm{v})$ and hydrochloric acid $(1 \mathrm{~N})$ were prepared. The reagents used in Method B were aqueous solution of Ferric chloride $(0.003 \mathrm{M}), 1,10$ phenanthroline $(0.02 \mathrm{M})$ and o-phosphoric acid $(0.2 \mathrm{M})$.

\section{Procedure}

Standard stock solution: A standard stock solution containing $1 \mathrm{mg} / \mathrm{ml}$ was prepared by dissolving $100 \mathrm{mg}$ of Nelfinavir Mesylate in $100 \mathrm{ml}$ of methanol. From this, a working standard solution containing $80 \mu \mathrm{g} / \mathrm{ml}$ (Method A) and $50 \mu \mathrm{g} / \mathrm{ml}$ (Method B) were prepared with methanol.

\section{Method A}

Into a series of graduated $10 \mathrm{ml}$ test tubes, $0.5-1.5 \mathrm{ml}(1 \mathrm{ml}=80 \mu \mathrm{g} / \mathrm{ml})$ of working standard drug solution was pipetted separately and to each test tube $0.5 \mathrm{ml}$ of $0.3 \% \mathrm{w} / \mathrm{v}$ ferric chloride solution was added and shaken for $2 \mathrm{~min}$. Then $0.5 \mathrm{ml}$ of $0.1 \% \mathrm{w} / \mathrm{v}$ potassium ferricyanide was added and shaken for $2 \mathrm{~min}$. To this solution, $0.5 \mathrm{ml}$ of $1 \mathrm{~N}$ hydrochloric acid was added and shaken for $2 \mathrm{~min}$. Then final volume was made up to $10 \mathrm{ml}$ with distilled water. The absorbance of the bluish green color developed was measured at $720 \mathrm{~nm}$ against reagent 
blank within $25 \mathrm{mts}$. The sample solution was also treated in the similar manner. The amount of drug in the sample was computed from Beer-Lambert plot.

\section{Method B}

Aliquots of standard solutions containing $0.1-2.0 \mathrm{ml} \quad(1 \mathrm{ml}=50 \mu \mathrm{g} / \mathrm{ml})$ were transferred into series of $10 \mathrm{ml}$ graduated test tubes, $3 \mathrm{ml}$ of ferric chloride $(0.003 \mathrm{M})$ and $1.5 \mathrm{ml}$ of 1,10 phenanthroline $(0.02 \mathrm{M})$ were added to each test tube. The test tubes were then heated on water bath for $15 \mathrm{~min}$ at a temperature of $70^{\circ} \mathrm{c}$, then cooled to room temperature and $1 \mathrm{ml}$ of o-phosphoric acid $(0.2 \mathrm{M})$ was added to each test tube and the total volume was brought to $10 \mathrm{ml}$ with distilled water. The absorbance of the blood red colored species was measured at $510 \mathrm{~nm}$ against reagent blank. The amount of Nelfinavir Mesylate present in the sample solution was computed from its calibration curve.

\section{Preparation of sample solution}

Tablets containing Nelfinavir Mesylate were successfully analyzed by the proposed methods: Twenty tablets of Nelfinavir Mesylate (NELFIN, $250 \mathrm{mg}$, Genix Pharma) were accurately weighed and powdered. Tablet powder equivalent to $100 \mathrm{mg}$ of Nelfinavir was dissolved in $50 \mathrm{ml}$ of methanol and filtered and washed with methanol, the filtrate and washings were combined and the final volume was made to $100 \mathrm{ml}$ with methanol. The solution was suitably diluted and analyzed as given under the assay procedure for bulk samples. The results are represented in Table 1 . None of the excipients usually employed in the formulation of tablets interfered in the analysis of Nelfinavir, by the proposed methods

\section{Recovery Studies}

To ensure the accuracy and reproducibility of the results obtained, recovery experiments were performed by adding known amounts of pure drug to the previously analysed formulated samples and these samples were reanalyzed by the proposed method. The percentage recoveries thus obtained were given in Table 1 .

Table 1. Assay of Nelfinavir Mesylate in Tablets.

\begin{tabular}{cccccc}
\hline $\begin{array}{c}\text { Sample } \\
(\text { Tablet })\end{array}$ & $\begin{array}{c}\text { Labeled Amount } \\
(\mathrm{mg})\end{array}$ & \multicolumn{2}{c}{$\begin{array}{c}\text { Amount Obtained }(\mathrm{mg}) * \\
\text { by proposed method }\end{array}$} & \multicolumn{2}{c}{$\begin{array}{c}\text { \% Recovery by the } \\
\text { proposed method }\end{array}$} \\
\cline { 3 - 6 } & & $\begin{array}{c}\text { Method } \\
\text { A. }\end{array}$ & $\begin{array}{c}\text { Method } \\
\text { B }\end{array}$ & $\begin{array}{c}\text { Method } \\
\text { A. }\end{array}$ & $\begin{array}{c}\text { Method } \\
\text { B }\end{array}$ \\
\hline 1 & 250 & 253.30 & 252.47 & $100.5 \%$ & $100.9 \%$ \\
2 & 250 & 253.10 & 252.31 & $99.8 \%$ & $100.9 \%$ \\
3 & 250 & 253.00 & 252.10 & $100.6 \%$ & $100.8 \%$ \\
\hline
\end{tabular}

*Average of three determinations.

** After spiking the sample.

\section{Results and Discussion}

The optimum conditions were established by varying one parameter at a time and keeping the others fixed and observing the effect on absorbance of chromogen. The effect of temperature of the reaction, quantity, concentration and addition of various reagents were studied, optimized after several experiments and incorporated in the procedure.

In the Method A, the drug Nelfinavir reduces ferric chloride to ferrous ions, which in turn couples with reagents having divalent iron like potassium ferricyanide to form bluish 
green colored potassium ferro ferrous complex. The absorption spectrum of the colored solution showed maximum absorption at $720 \mathrm{~nm}$. The bluish green color was found to be stable for $25 \mathrm{~min}$ only. In the Method B Nelfinavir Mesylate reduces ferric chloride to ferrous form, which forms complex with 1.10-phenanthroline to yield blood red colored chromogen. The optical characteristics such as absorption maxima, Beer's law limits, molar absorptivity and Sandell's sensitivity are presented in Table 2.

The regression analysis using the method of least squares was made for slope $(\mathrm{m})$, intercept (b) and correlation obtained from different concentrations and the results are summarized in Table 2.

Table 2. Optical Characteristics and Precision Data.

\begin{tabular}{lcc}
\hline & Method A & Method B \\
\hline$\lambda_{\text {max }}$ (nano meters ) & 720 & 510 \\
Beer's law limits (micrograms/ml) & $4-12$ & $0.5-10$ \\
Molar absorptivity (1/mol.cm) & $3.46 \times 10^{3}$ & $0.6 \times 10^{3}$ \\
Sandell's sensitivity & 0.192 & 0.106 \\
(micrograms/cm $/ 0.001$ absorbance unit) & & \\
Regression Equation* (Y) & & \\
Slope (m) & 0.008 & 0.007 \\
Intercept (c) & -0.247 & 0.018 \\
Correlation Coefficient(r) & 0.9998 & 0.998 \\
Precision (\% Relative Standard Deviation) & 0.923 & 0.2986 \\
Standard error of mean & 0.0049 & 0.0288 \\
\hline
\end{tabular}

* $\mathrm{Y}=\mathrm{mx}+\mathrm{c}$, where $\mathrm{X}$ is the concentration in micrograms $/ \mathrm{ml}$ and $\mathrm{Y}$ is absorbance unit.

\section{Conclusions}

The proposed methods are economical, simple, sensitive and accurate for the routine estimation of Nelfinavir Mesylate in bulk as well as in tablet form.

\section{Acknowledgement}

The authors are grateful to M/s Aurobindo Pharma, Hyderabad for the supply of Nelfinavir Mesylate as a gift sample and to the Principal, Sultan-Ul-Uloom college of Pharmacy, Hyderabad, for providing the necessary facilities to carry out the research work.

\section{References}

1. The Merck Index, XIII edition, 2001,Merck Research Laboratories, (Monograph No: 6471) p1154.

2. Sean C Sweetman, Martindale-The Complete Drug Reference, 34th edition, 2005 p650.

3. Ellen $\mathrm{Y} \mathrm{Wu}$, james $\mathrm{M}$ Wilkinson, Daniel G Naret, Valerie L Daniels, Linda Jefferson Williams, Deborah A Khalil and Bhasker V Shetty, J.Chromatogr.B, 1997, 695, 373-380.

4. Van Heeswijk R P G, Hoetelmans R M W, Harns R., Meenhorst P L, Mulder J W, Lange J M A and Beijnen J H, J.Chromatogr.B, 1998, 719,159-168.

5. Aymard G, Legrand M, Trihereau N and Bdiquet, Chromatogr.B, 2000, 744, 227-240. 
6. Verne A Simon, Mamadou D Thiam and Levin C Lipford, J. Chromatogr. A, 2001, 913, 447-453.

7. Paul Metz, Sue.J Kohlhepp and Gilbert D N, J. Chromatogr. B, 2002, 773,159.

8. Michele L Turner, Kedria Reed-walker, Jennifer R King and Edward P Acosta, J.Chromatogr.B, 2003, 784, 331-341.

9. Valerie A Frerichs, robin Di Francesco and Gene D Morse, J. Chromatogr.B, 2003, 787, 393-403.

10. Katharina M Rentsch, J.Chromatogr.B, 2003, 788, 339-350.

11. Rao, Seshagiri V M Mohan Reddy, Tadi R S Rao, Isukapatla N, J.Analytical Chemistry, 2004, 59(6), 552-556.

12. Rao S V, Murali Mohan Reddy, Rama Subba T, Prasad U and Viplava Sastry C S P, Journal of Institution of Chemists; 2003, 75(2), 46 .

13. Rao S V, Murali Mohan Reddy, Rama Subba T, Prasad U and Viplava Sastry C S P, Asian J. Chem, 2003,15(2), 971-976. 


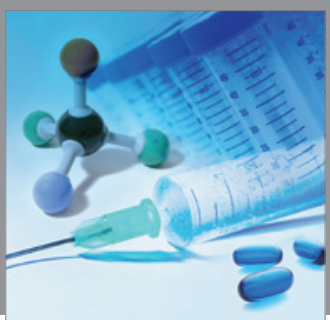

International Journal of

Medicinal Chemistry

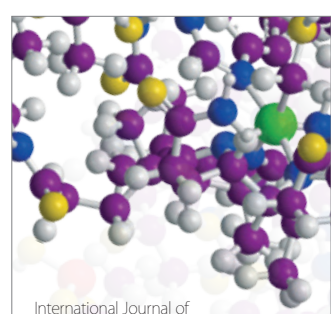

Carbohydrate Chemistry

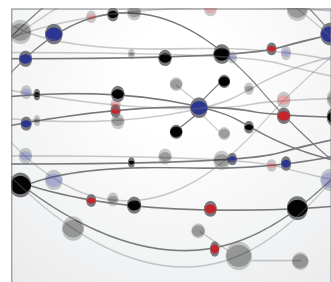

The Scientific World Journal
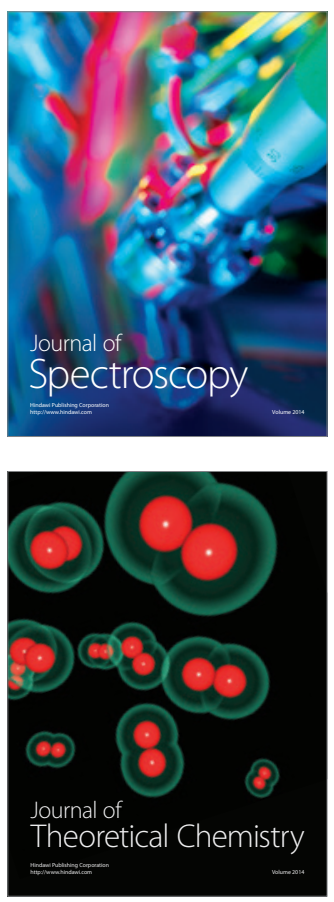
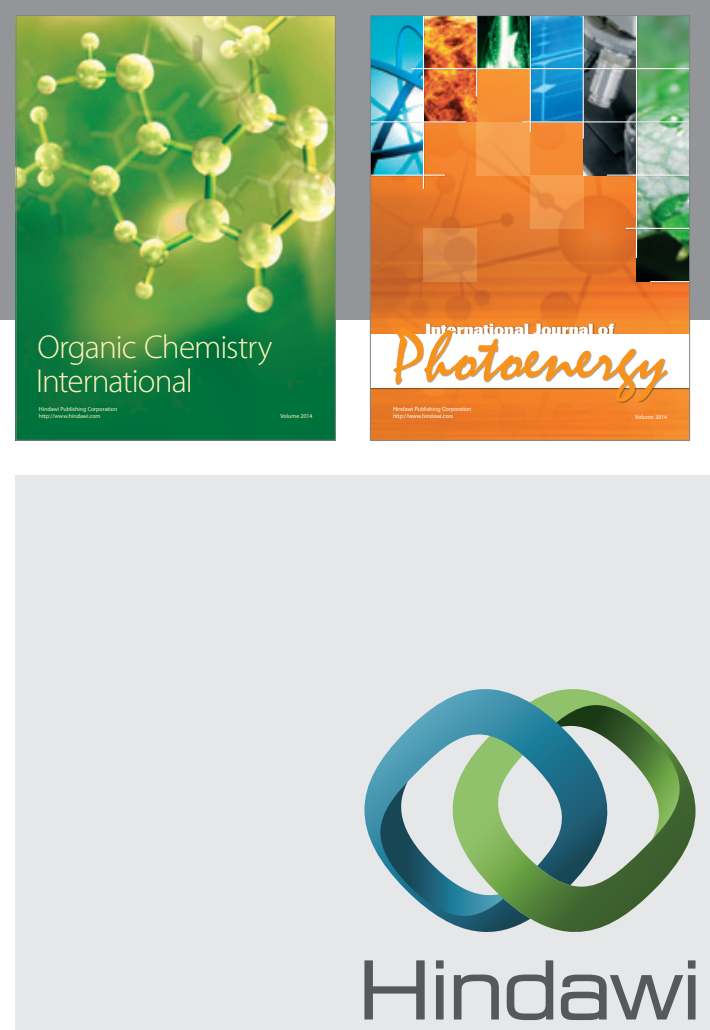

Submit your manuscripts at

http://www.hindawi.com
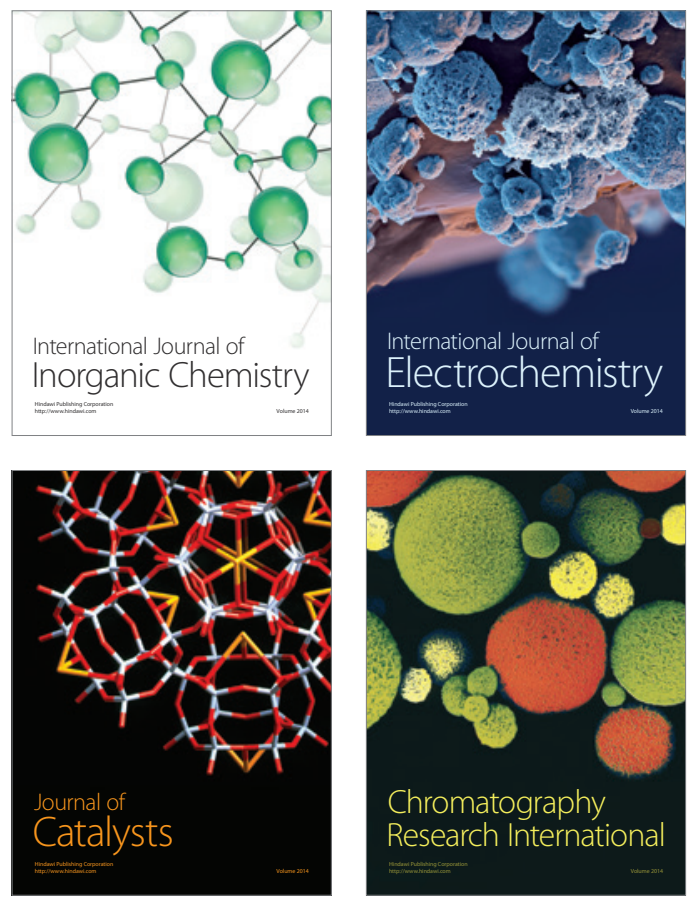
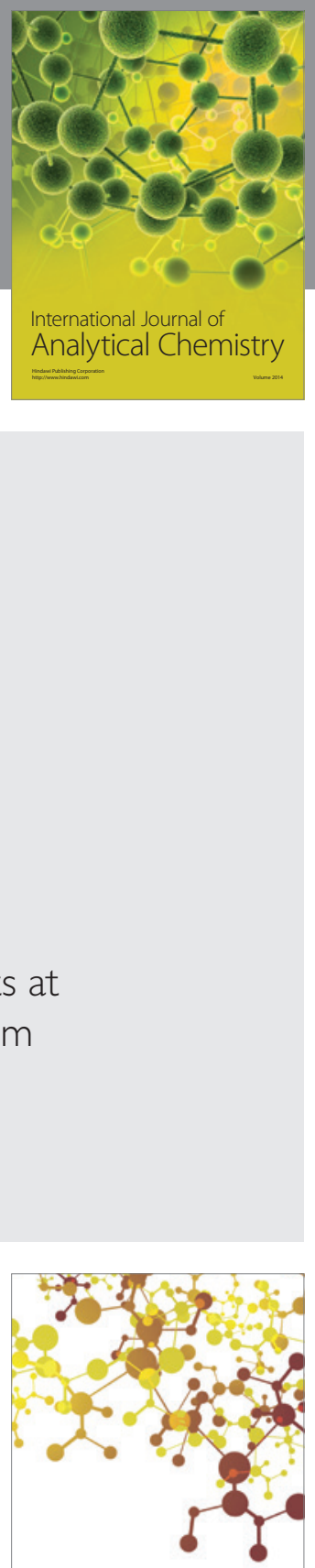

Journal of

Applied Chemistry
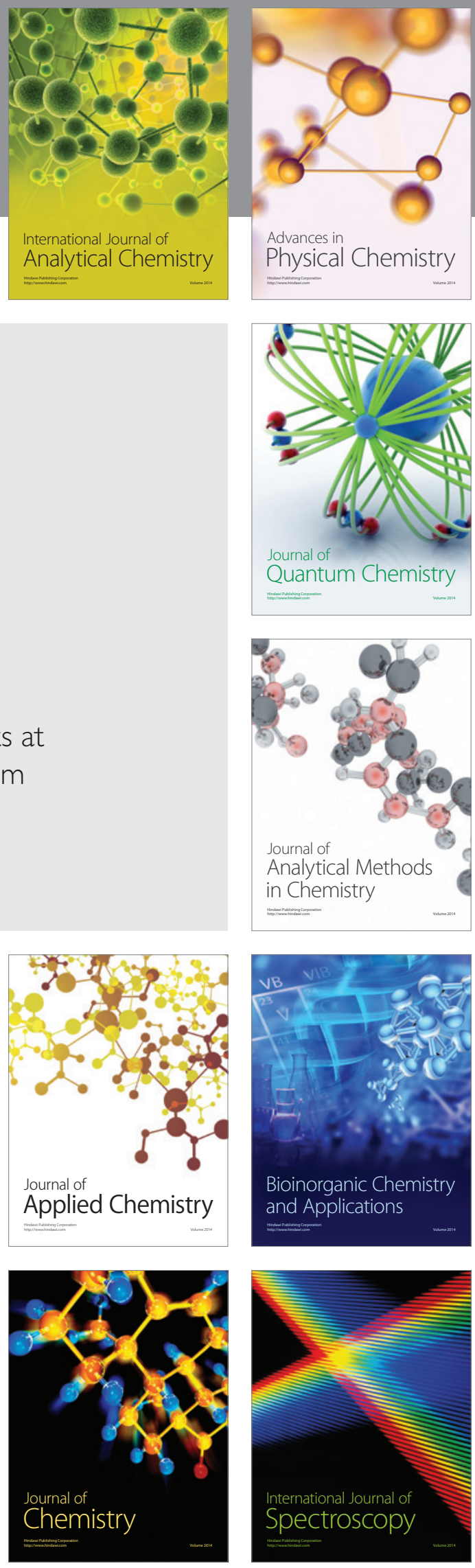